MARLENA KILIAN

Wydział Nauk Pedagogicznych

Uniwersytet Kardynała Stefana Wyszyńskiego

Warszawa
Forum Pedagogiczne 2016/1

Wpłynęło: 11.01.2016 Zatwierdzono do druku: 23.03.2016

\title{
STUDENCI Z NIEPEŁNOSPRAWNOŚCIAMI: DOŚWIADCZENIA, POTRZEBY, WYZWANIA
}

Streszczenie: $\mathrm{W}$ artykule dokonano analizy działalności polskich uczelni wyższych na rzecz stwarzania studentom z niepełnosprawnościami warunków do pełnego udziału w procesie kształcenia, a także scharakteryzowano podejmowane w tym zakresie zadania w odniesieniu do: samych studentów z niepełnosprawnością, kadry akademickiej, wspólnoty studenckiej oraz otoczenia fizycznego. Przedstawiono w zarysie dotychczasowe doświadczenia oraz obecne wyzwania w dziedzinie dostosowywania kształcenia akademickiego do potrzeb osób $\mathrm{z}$ różnego rodzaju niepełnosprawnościami.

Słowa kluczowe: niepełnosprawność, edukacja, studia, adaptacja, inkluzja

\section{Wprowadzenie}

Podstawą rozwoju nowoczesnych społeczeństw jest dostęp do wiedzy, również w dziedzinie kształcenia, $\mathrm{z}$ drugiej strony miarą tego rozwoju jest ich stosunek do osób chorych i niepełnosprawnych. Polskie standardy prawne zakładają równość wszystkich obywateli w dostępie do edukacji. Doświadczenia praktyczne polskich uczelni pokazują jednak, że wdrażanie wymogu zapewnienia równych szans studentom z niepełnosprawnościami jest procesem długotrwałym, pełnym wyzwań w zaspokajaniu ich specyficznych potrzeb edukacyjnych.

Dostosowywanie uczelni wyższych do potrzeb studentów z niepełnosprawnościami wpisuje się w koncepcję edukacji włączającej, wymagającej tworzenia wspólnej przestrzeni edukacyjnej dla wszystkich uczących się osób, bez względu na stan ich zdrowia i sprawności. Edukacja włączająca realizowana na poziomie akademickim jest ukoronowaniem całego dotychczasowego procesu usprawniania, edukacji i wychowania osób niepełnosprawnych, nastawionego, podobnie jak w przypadku osób zdrowych, na uzyskanie maksymalnej życiowej samodzielności. Wymaga stworzenia takich warunków kształcenia w edukacji głównego nurtu, aby odpowiadały one na specyficzne potrzeby edukacyjne studentów z różnego 
rodzaju niepełnosprawnościami. Zdaniem Dagmary Nowak-Adamczyk „realizacja podejścia włączającego osoby niepełnosprawne w główny nurt kształcenia akademickiego oznacza stworzenie w uczelni systemu wsparcia edukacyjnego obejmującego działania bezpośrednio skierowane do studentów, ale także do wykładowców jako osób przekazujących wiedzę i umiejętności z danej dziedziny wszystkim studentom" (Nowak-Adamczyk 2014, s. 203).

W praktyce za system wsparcia edukacyjnego na poziomie akademickim odpowiadają specjalnie w tym celu powołane jednostki, najczęściej nazywane biurami ds. osób niepełnosprawnych (BON). W swej działalności skupiają się one na współpracy z niepełnosprawnymi studentami oraz ich otoczeniem społecznym, tj. pełnosprawnymi studentami oraz pracownikami i wykładowcami uczelni, a także na adaptacji otoczenia fizycznego (zewnętrznego i wewnętrznego budynków). Celem działalności biur osób niepełnosprawnych jest wyrównywanie szans niepełnosprawnych studentów w dostępie do oferty edukacyjnej i programu kształcenia oraz ich realizacji przy zachowaniu obowiązujących standardów jakości kształcenia akademickiego.

Koncepcja edukacji włączającej rozwijała się w wyniku postępujących zmian w postrzeganiu niepełnosprawności - przejścia od medycznego modelu niepełnosprawności, upatrującego deficytów w osobie o obniżonej sprawności, która $\mathrm{z}$ tego powodu skłaniana jest do dostosowania się do otoczenia kreowanego wedle potrzeb zdrowej większości, do modelu społecznego, szukającego w otoczeniu zewnętrznym (fizycznym i społecznym) potencjału adaptacyjnego dla potrzeb niepełnosprawnej mniejszości. W modelu społecznym niepełnosprawność wywodzi się z zaburzonej relacji między sprawnością danej osoby a wymogami jej środowiska. W tym przypadku otoczenie fizyczne i społeczne może generować bariery obniżające sprawność funkcjonowania niektórych ludzi, tym samym decydując o ich niepełnosprawności. W konsekwencji działania usprawniające koncentrują się nie tylko na podnoszeniu sprawności samej osoby, ale również na dostosowywaniu otoczenia do jej określonych potrzeb, traktowanych w sposób neutralny. Osoba niepełnosprawna, posiadając te same co osoby pełnosprawne prawa obywatelskie, przestaje być otaczana specjalną troską, korzystać ze świadczeń socjalnych czy z pomocy charytatywnej. Jest pełnoprawnym obywatelem, który z uwagi na swe specyficzne cechy wymaga pewnych adaptacji, wdrażanych w imię wyrównywania jego szans, również na gruncie edukacji.

W kontekście kształcenia niepełnosprawność nie jest zatem rozpatrywana w kategorii deficytów, a określonych potrzeb edukacyjnych. Edukacja włączająca unika wręcz traktowania potrzeb studentów z niepełnosprawnościami jako specjalnych. Dąży bowiem do zapewnienia im normalnej ścieżki edukacyjnej, a to oznacza odchodzenie od „specjalnych” metod w zaspokajaniu „specjalnych” potrzeb studentów. Osoby z niepełnosprawnościami proponuje postrzegać w kategoriach wewnętrznego zróżnicowania i pozytywnie odpowiadać na ich specyficzne potrzeby. W ujęciu tym to nie student zobowiązany jest dopasować się do gotowego systemu, 
skrojonego na miarę większości. Zmieniać się mają elementy systemu kształcenia, zgodnie z potrzebami wszystkich uczących się osób (Krzymowska 2014).

\section{Edukacja studentów $\mathrm{z}$ niepełnosprawnościami w liczbach}

Do niedawna studia wyższe funkcjonowały jako forma kształcenia elitarnego, dostępnego dla nielicznych, szczególnie predysponowanych, i pozostawały poza zasięgiem wielu pełnosprawnych obywateli, a tym bardziej tych, którzy doświadczali funkcjonalnych ograniczeń. Przemiany polityczno-gospodarcze, jakie nastąpiły w Polsce po 1989 roku, wzrost aspiracji edukacyjnych w społeczeństwie, rozprzestrzenienie się idei edukacji integracyjnej w wymiarze teoretycznym i praktycznym w połączeniu ze zmniejszeniem się liczby osób wkraczających w dorosłość z powodu niżu demograficznego przyczyniły się do zwiększenia dostępności studiów wyższych również dla osób z niepełnosprawnością.

Według danych Głównego Urzędu Statystycznego (GUS 2014) w latach 1998-2013 nastąpił znaczący wzrost liczby studentów: w roku 1998 roku studiowały w Polsce 814574 osoby, podczas gdy w roku 2013 osób takich było 1549 877. W tym samym okresie odnotowano ogromny wzrost liczby studentów z niepełnosprawnością: w 1998 roku było ich 1186, a 15 lat później już 31 613. Pomimo tak ogromnej zmiany w liczbie studentów niepełnosprawnych stanowiących społeczność akademicką odsetek niepełnosprawnych absolwentów wciąż wynosi $6,7 \%$ w porównaniu z 20,1\% osób bez niepełnosprawności (BAEL 2011). Niemniej odsetek niepełnosprawnych osób z wyższym wykształceniem stale wzrasta. Zmienia się również struktura studentów z niepełnosprawnością w kierunku wzrostu liczby osób ze znacznymi dysfunkcjami (Giermanowska, Racław 2014).

Osoby niepełnosprawne stanowią ponad 10\% społeczeństwa, podczas gdy studenci z orzeczoną niepełnosprawnością to około 2,0\% ogółu studiujących (GUS 2014). Być może ich rzeczywista liczba jest większa, ponieważ niektóre osoby z funkcjonalnymi dysfunkcjami nie ujawniają orzeczenia o niepełnosprawności, rezygnując np. z pobierania przysługującego im stypendium specjalnego czy wsparcia BON-u. Wśród niepełnosprawnych studentów liczną grupę stanowią osoby z zaburzeniami sprawności ruchowej (5316 osób chodzących, 503 osoby niechodzące), następne są osoby niewidome i słabowidzące (1874) oraz niesłyszące i słabosłyszące (1491). Największą grupę tworzą studenci z innymi rodzajami niepełnosprawności (13 804) (GUS 2014).

Niestety, pomimo wzrastającego udziału studentów z niepełnosprawnościami w społeczności akademickiej, tylko na połowie polskich uczelni (47,6\%) pracuje pełnomocnik rektora lub inna osoba wyznaczona do kontaktu z niepełnosprawnymi kandydatami na studentów (Waszkielewicz 2007), co negatywnie rzutuje na stopień ich dostosowania do specyficznych potrzeb edukacyjnych osób doświadczających różnego rodzaju i stopnia niepełnosprawności. 


\section{Podstawy prawne edukacji studentów z niepełnosprawnościami}

Wzrost liczby studentów z niepełnosprawnością umożliwiła zmiana regulacji prawnych, w największej mierze Ustawa $z$ dnia 27 lipca 2005 roku. Prawo o szkolnictwie wyższym. W myśl tego dokumentu dostęp do studiów ma mieć każdy, kto spełnia wymogi merytoryczne, bez względu na ograniczenia fizyczne i zdrowotne. Uczelnie zobligowane zostały do "stwarzania osobom niepełnosprawnym warunków do pełnego udziału w procesie kształcenia i w badaniach naukowych”.

Rozporzadzenie Ministra Nauki i Szkolnictwa Wyższego z dnia 25 września 2014 roku w sprawie warunków, jakim musza odpowiadać postanowienia regulaminu studiów w uczelniach, par. 2, stanowi: „Regulamin studiów określa sposób dostosowania organizacji i właściwej realizacji procesu dydaktycznego do szczególnych potrzeb studentów będących osobami niepełnosprawnymi, w tym dostosowania warunków odbywania studiów do rodzaju niepełnosprawności”.

Środki na finansowanie dostosowywania uczeni i kształcenia do potrzeb osób z niepełnosprawnościami pochodzą ze źródeł własnych uczelni oraz projektów unijnych, a od 2007 roku pozyskiwane są także ze specjalnej dotacji budżetowej na realizację działań koniecznych do pełnego wywiązania się z obowiązków wobec studentów niepełnosprawnych nałożonych przez ustawę. Do 2011 roku w ramach dotacji uczelnie realizowały zadania związane z „kształceniem i rehabilitacją leczniczą studentów niepełnosprawnych", natomiast od 2012 roku polegają one na „stwarzaniu studentom i doktorantom, będącym osobami niepełnosprawnymi, warunków do pełnego udziału w procesie kształcenia”. Cele wydatkowania dotacji nakreślono zatem szerzej - obecnie wykraczają one poza dostosowywanie samego procesu kształcenia i odnoszą się do wszelkich działań nastawionych na stwarzanie warunków do pełnego udziału niepełnosprawnych w procesie kształcenia. W myśl obecnych regulacji dotacjami należy objąć również studentów studiów doktoranckich, jednak z wyłączeniem zadań związanych z rehabilitacją leczniczą. Niestety, ich wydatkowanie może odbywać się z pominięciem bezpośrednich potrzeb studentów niepełnosprawnych i skupiać się na zadaniach ogólnouczelnianych. Decyzja w tym zakresie zależy od dobrej woli władz uczelni.

Prawo do nauki osób z obniżoną sprawnością chronione jest przez konstytucję oraz prawo międzynarodowe. Zgodnie z art. 32 Konstytucji Rzeczypospolitej Polskiej: „Wszyscy są wobec prawa równi. Wszyscy mają prawo do równego traktowania przez władze publiczne. Nikt nie może być dyskryminowany w życiu politycznym, społecznym lub gospodarczym z jakiejkolwiek przyczyny”, według zaś art. 70 ust. 4: „Władze publiczne zapewniają obywatelom powszechny i równy dostęp do wykształcenia”. Z kolei w art. 24 ust. 5 Konwencji ONZ o prawach osób niepetnosprawnych (edukacja) jest mowa o tym, że: „Państwa - Strony zagwarantują osobom niepełnosprawnym dostęp do szkolnictwa wyższego, zawodowego, edukacji dorosłych i kształcenia ustawicznego bez dyskryminacji i na równych zasadach 
z innymi obywatelami. W tym celu Państwa - Strony zagwarantują racjonalne dostosowanie do potrzeb osób niepełnosprawnych".

\section{Przystosowanie uczelni do potrzeb studentów z niepełnosprawnościami}

Polskie badania (Waszkielewicz 2007) oceniające dostępność szkolnictwa wyższego dla osób z niepełnosprawnością wzrokową wykazały, że połowa studentów $\mathrm{z}$ różnego typu niepełnosprawnościami uznaje swoją uczelnię za nieprzystosowaną do ich potrzeb. Na jednej trzeciej z ponad 400 przebadanych szkół wyższych nie istniały żadne rozwiązania techniczne ani organizacyjne wspomagające funkcjonowanie osób z dysfunkcją wzroku, a ponad połowa z nich nie miała pomysłu na poprawę sytuacji takich osób. Około 30\% uczelni publicznych i 4\% niepublicznych deklarowało posiadanie struktur upoważnionych do reprezentowania interesów studentów niepełnosprawnych (pełnomocnika rektora lub jednostkę administracyjną). Około $27 \%$ wyższych szkół publicznych versus $13 \%$ niepublicznych objętych badaniem posiadało w statucie uczelni zapisy dotyczące studentów niepełnosprawnych.

Te same badania (Waszkielewicz 2007) ujawniły, że egzamin w formie specjalistycznej (przy pomocy udźwiękowionego komputera, w alfabecie brajla, w druku powiększonym lub przy pomocy lektora) przeprowadziło wobec niewidomych i słabowidzących kandydatów około 10\% uczelni, niemal wyłącznie publicznych. Niecała połowa badanych instytucji szkolnictwa wyższego ( $45 \%$ publicznych i $47 \%$ niepublicznych) deklarowała udostępnianie studentom z dysfunkcją wzroku materiałów dydaktycznych w postaci elektronicznej, co trzecia publiczna (34\%) i niemal co czwarta uczelnia niepubliczna (23\%) posiadała udźwiękowiony sprzęt komputerowy. Wyposażenie bibliotek w urządzenia umożliwiające przetwarzanie materiałów drukowanych do postaci elektronicznej zgłosiło $32 \%$ uczelni publicznych i $21 \%$ niepublicznych. Funkcje asystenta dla osoby niepełnosprawnej przewidziało $23 \%$ uczelni publicznych i 11\% niepublicznych. Wciąż jednak w połowie badanych instytucji akademickich nagrywanie wykładów uzależnione było od indywidualnej zgody wykładowców, a tylko w około jednej trzeciej odbywało się w oparciu o obowiązujące zapisy regulaminowe. W kwestii poprawy sytuacji studentów niewidomych i słabowidzących za najpilniejszą potrzebę uznano wyposażenie jednostek w sprzęt techniczny, taki jak udźwiękowione komputery czy skanery (uważała tak jedna piąta przedstawicieli szkół publicznych i niepublicznych).

W badaniach przeprowadzonych na próbie 103 niepełnosprawnych studentów lub absolwentów (Szpunar 2010) zdecydowana większość ankietowanych stwierdziła, że studia pozwoliły im się dowartościować (95\%), poczuć, że są tak samo sprawni jak inni (80\%). Aż 70\% badanych uznało studia za najlepszy okres w swym życiu. Sferę akademickiego życia społecznego respondenci ocenili nadzwyczaj dobrze. Niemal wszyscy zawsze mogli liczyć na pomoc kolegów i koleżanek ze studiów (90\%) oraz życzliwość i pomoc wykładowców (85\%). W opinii 70\% badanych wykładowcy nie 
traktowali inaczej studentów pełnosprawnych i niepełnosprawnych, natomiast zdaniem $20 \%$ ankietowanych musieli oni udowadniać wykładowcom, że są tak samo dobrzy jak studenci pełnosprawni (20\%). Niemal wszyscy wyrażali przekonanie (95\%), że wykładowcy nie powinni stosować żadnych taryf ulgowych wobec niepełnosprawnych. Znacznie gorzej studenci oceniali dostosowanie do ich potrzeb środowiska fizycznego, wskazując na bariery architektoniczne i infrastrukturalne. Połowa z nich (50\%) stwierdziła, że ich uczelnia w ogóle nie była dostosowana do potrzeb osób z dysfunkcjami. Również połowa ankietowanych niepełnosprawnych studentów nie znała żadnego pracownika uczelni, który służyłby wsparciem, np. w kwestii zdobycia informacji co do przysługujących świadczeń.

Małgorzata Perdeus-Białek i Dagmara Nowak-Adamczyk (Perdeus-Białek, Nowak-Adamczyk 2013, s. 12-13), nawiązując do Konwencji ONZ o prawach osób niepełnosprawnych, sformułowały szereg zasad zwiększających efektywność wsparcia udzielanego studentom niepełnosprawnym, umożliwiających osiągnięcie równowagi między równym traktowaniem a utrzymaniem standardów akademickich oraz określenie granicy adaptacji, czyli rozgraniczenia między przywilejami dla studenta niepełnosprawnego a wyrównywaniem jego szans:

1. Indywidualizacja - adaptacje procesu studiowania osoby niepełnosprawnej zawsze przygotowywane są w odpowiedzi na jej indywidualne potrzeby edukacyjne, wynikające ze specyfiki obecnego stanu zdrowia oraz danego kursu, w tym warunków, w jakich się on odbywa.

2. Podmiotowość, czyli uwzględnianie autonomii osoby niepełnosprawnej i jej prawa do decydowania o sobie.

3. Rozwijanie potencjału osoby niepełnosprawnej w związku z wybranym przez nią kierunkiem studiów - oznacza ono dobór takich adaptacji, które pozwoliłyby studentowi/studentce nabywać wiedzę i rozwijać praktyczne umiejętności.

4. Racjonalność dostosowania - proponowanie adaptacji racjonalnych ekonomicznie, skutecznie wyrównujących szanse osoby niepełnosprawnej oraz gwarantujących zachowanie standardu akademickiego.

5. Utrzymanie standardu akademickiego, czyli przygotowanie adaptacji studiów przy jednoczesnym utrzymaniu kryteriów merytorycznych obowiązujących wszystkich studentów danego kierunku/specjalności.

6. Zastosowanie adaptacji najbliższych standardowemu przebiegowi zajęć, to znaczy takich, które nie mają charakteru przywilejów dla osoby niepełnosprawnej, ale w sposób racjonalny wyrównują jej szanse w dostępie do oferty kształcenia uznanej za optymalną na danym kierunku.

7. Równe prawa i obowiązki, czyli nie tylko dbałość o przestrzeganie równych praw dla osób niepełnosprawnych, ale również (dzięki zapewnieniu tych praw) egzekwowanie wypełniania obowiązków studenckich w takim samym stopniu jak w przypadku studentów pełnosprawnych. 


\section{Działalność pełnomocnika/biura ds. osób niepełnosprawnych}

Uczelnie, prawnie zobowiązane do wdrażania systemowych rozwiązań wspierających studentów niepełnosprawnych w procesie dydaktycznym i badaniach naukowych, robią to poprzez działania pełnomocnika rektora ds. osób niepełnosprawnych lub biura ds. osób niepełnosprawnych. Zwykle jednostki te stanowią ciało doradcze dla władz uczelni. Podejmują ogólnouczelniane oraz zindywidualizowane działania, ukierunkowane na wyrównywanie szans edukacyjnych studentów doświadczających niepełnosprawności, przy zachowaniu jednakowych dla ogółu studiujących wymogów merytorycznych. Niektóre z nich, zwykle te największe i najefektywniej działające, pełnią również funkcję promocyjną i informacyjną. Prowadzą wymianę doświadczeń w formie konferencji, kooperacji programów i grantów czy publikacji (Giermanowska, Racław 2014).

Działania podejmowane przez pełnomocnika rektora ds. osób niepełnosprawnych lub biura ds. osób niepełnosprawnych:

- informacyjne, np.: spotkania promocyjne w szkołach ponadgimnazjalnych, udział w dniach otwartych uczelni, przygotowywanie ulotek informacyjnych dla niepełnosprawnych kandydatów na studia, zaangażowanie w proces rekrutacji, administrowanie witryną internetową, obecność w lokalnej prasie, radiu i telewizji, wydawanie publikacji (naukowych, informatorów, czasopism, broszur, ulotek informacyjnych itp.);

- szkoleniowo-edukacyjne, np.: szkolenia dla studentów z niepełnosprawnościami, wykładowców i pracowników uczelni, współorganizowanie konferencji na temat niepełnosprawności w kontekście kształcenia, budzenie świadomości własnych potrzeb wynikających z doświadczanej niepełnosprawności i posiadania prawa do ich zaspokajania;

- konsultacyjne, np. indywidualne i grupowe konsultacje w kwestii formalnych i prawnych aspektów kształcenia osób z niepełnosprawnościami;

- prawno-administracyjne, np.: gromadzenie danych statystycznych, opiniowanie wniosków o adaptację procesu dydaktycznego czy procedury egzaminacyjnej, urlop okolicznościowy ze względów zdrowotnych, stypendium specjalne, również udział w tworzeniu wewnętrznych aktów normatywnych, zasad wydatkowania dotacji ministerialnej;

- organizacyjne, np. przygotowywanie spotkań studentów pierwszego roku z prorektorem ds. kształcenia oraz przedstawicielami BON-u, a także dni adaptacyjnych;

- integracyjne, np.: prowadzenie spotkań, imprez integracyjnych i uświadamiających w społecznościach studentów niepełnosprawnych (m.in. cotygodniowych towarzyskich spotkań przy herbacie), w grupach studentów niepełnosprawnych i pełnosprawnych (m.in. spotkań okolicznościowych, kulturalnych, wspólnych konferencji, imprez plenerowych), skierowanych 
do pracowników uczelni oraz szerszej pozaakademickiej społeczności, na poziomie uczelnianym, międzyuczelnianym i ogólnopolskim;

- ewaluacyjne, np.: cykliczne aktualizowanie oceny specyficznych potrzeb edukacyjnych studentów, wynikających z różnego rodzaju niepełnosprawności, audyt dostępności otoczenia fizycznego;

- wspierające, np.: udzielanie niepełnosprawnym studentom wielorakiego wsparcia (edukacyjnego, psychologicznego, społecznego itp.), usługi asystentów osobistych, zajęcia z zakresu orientacji przestrzennej dla osób niewidomych, obozy szkoleniowe i warsztaty edukacyjne;

- adaptacyjne, np.: alternatywne zajęcia $\mathrm{z}$ wychowania fizycznego, lektoraty zaadaptowane do potrzeb studentów niewidomych oraz niesłyszących, wyposażenie sal w pętle induktofoniczne dla potrzeb osób słabosłyszących, obecność na zajęciach tłumacza języka migowego, adaptacja egzaminów/ zaliczeń do indywidualnych możliwości osób niepełnosprawnych;

- kooperacyjne, np.: współpraca z jednostkami zewnętrznymi (innymi uczelniami, instytucjami, organizacjami, stowarzyszeniami, fundacjami) i wewnętrznymi (senatem uczelni i komisjami senackimi, dziekanami, koordynatorami praktyk studenckich, akademickim biurem karier, działem rekrutacji, jakości kształcenia, wykładowcami).

Działania bezpośrednio wspierające studentów z niepełnosprawnościami to np.:

- możliwość zakwaterowania niepełnosprawnego studenta w akademiku wraz asystentem,

- ustalenie indywidualnego planu studiów i programu nauczania,

- umożliwienie zapisania się na określone zajęcia (np. WF-u) przed rozpoczęciem rejestracji pozostałych studentów,

- uwzględnianie potrzeb niepełnosprawnych studentów podczas przydzielania sal dydaktycznych, np. na parterze, w jednej sali w ciągu dnia (ułatwienie dostępu),

- umożliwienie wykonywania notatek z zajęć w formie alternatywnej na własny użytek (np. nagrywania, robienia zdjęć, korzystania z innych urządzeń lub z dodatkowej pomocy osoby robiącej notatki),

- prowadzenie wykładów z użyciem mikrofonu,

- przekazywanie studentom z niepełnosprawnością materiałów dydaktycznych w wersji elektronicznej,

- uczestnictwo w zajęciach asystentów studentów z niepełnosprawnością,

- umożliwienie zmiany formy weryfikacji wiedzy z ustnej na pisemną bądź z pisemnej na ustną, wydłużenie czasu egzaminu lub zaliczenia,

- przedłużenie sesji egzaminacyjnej poza terminy przewidziane w przepisach,

- przywilej załatwiania spraw w dziekanatach poza kolejnością,

- wywieszanie czytelnych graficznie informacji na tablicach znajdujących się na poziomie wzroku oraz udostępnianie ich w internecie, 
- przyznanie studentowi urlopu z powodu długotrwałej choroby potwierdzonej zaświadczeniem lekarskim lub z powodu innych zasadnych okoliczności losowych,

- zwiększenie dopuszczalnej absencji.

Warto zwrócić uwagę, że znaczna część wymienionych działań adaptacyjnych nie wymaga dodatkowych nakładów finansowych, a ich wprowadzenie wynika głównie ze świadomości specyficznych potrzeb niepełnosprawnych studentów i chęci ich zaspokajania.

Działania wymagające dodatkowego finansowania to np.:

- zapewnienie pełnej dostępności architektonicznej budynków,

- dostosowanie warunków zakwaterowania w akademikach,

- oferowanie specjalistycznego sprzętu wspomagającego podczas zajęć, np. przenośnych systemów FM, pętli induktofonicznej, tablicy interaktywnej itp.,

- przygotowanie stanowisk komputerowych (np. w bibliotece) dla studentów niepełnosprawnych,

- uruchomienie wypożyczalni sprzętu adaptacyjnego, jak np.: dyktafony, notatniki brajlowskie, przenośne systemy FM, urządzenia DAISY, urządzenia czytające, powiększalniki, elektroniczne lupy, GPS dla osób z dysfunkcją wzroku, laptopy, specjalistyczne oprogramowanie i klawiatury,

- adaptacja materiałów dydaktycznych,

- dostosowanie zajęć z wychowania fizycznego (uwzględnienie np. zajęć usprawniających na basenie lub siłowni, koszykówki i szermierki na wózkach),

- zaoferowanie specjalistycznych lektoratów w formie dostosowanej do typu niepełnosprawności,

- zorganizowanie dodatkowych uzupełniających zajęć dydaktycznych,

- wprowadzenie zajęć z zakresu poruszania się i orientacji przestrzennej dla osób niewidomych,

- zatrudnienie tłumaczy języka migowego na czas zajęć i zaliczeń dla studentów niesłyszących,

- zatrudnienie asystentów osobistych, np. dla osoby z niepełnosprawnością ruchową,

- zaoferowanie pomocy psychologicznej i prawnej,

- organizacja szkoleń i warsztatów dotyczących poprawy umiejętności psychospołecznych i aktywizacji zawodowej studentów z niepełnosprawnością,

- wyposażenie wydziałów w sprzęt ratunkowy.

\section{Działania wobec społeczności akademickiej}

Najbardziej zaawansowane adaptacje procesu kształcenia i najkosztowniejszy sprzęt nie wyrównają szans edukacyjnych niepełnosprawnych studentów, jeśli nie będą im towarzyszyć pozytywne postawy społeczne kadry naukowo-dydaktycznej, administracyjnej i studentów, ponieważ to one decydują o rzeczywistej integracji 
i adaptacji społecznej. Niedostosowanie procesu kształcenia do potrzeb osób z różnego rodzaju niepełnosprawnościami czy wręcz ich dyskryminacja biorą swój początek w stereotypach, uprzedzeniach i braku wiedzy. Niestety, bariery wynikające ze stereotypów i uprzedzeń najtrudniej poddają się zmianom, zwłaszcza w przypadku już ukształtowanych dorosłych (Paszkowicz, Garbat 2005).

W badaniach studenci pedagogiki specjalnej UMCS przyznali, że dla nich samych, jak również dla wielu wykładowców, kontakt z osobą niepełnosprawną jest sytuacją trudną i kłopotliwą (Kwaśniewska 2006). Wedle innych pomiarów w kontakcie z niepełnosprawnym niemal 60\% wykładowców odczuwało skrępowanie, $50 \%$ litość, 42\% lęk, a 14\% nieśmiałość, głównie z powodu braku wiedzy na temat tego, jak należy się wobec niego zachować (Fornalik 2006). Wynika stąd sygnalizowana przez pracowników dydaktycznych potrzeba lepszego przygotowania do pracy ze studentami niepełnosprawnymi.

Działalność pełnomocnika czy BON-u skupia się przede wszystkim na kształtowaniu wśród pracowników uczelni prawidłowych postaw wobec osób z różnego rodzaju niepełnosprawnościami i merytorycznym przygotowaniu kadry akademickiej do pracy z nimi. Wykładowcy są bowiem współodpowiedzialni za realizację wymogu zapewnienia niepełnosprawnym studentom równych szans w dostępie do kształcenia, czego nie dokonają bez uprzedniego zrozumienia ich specyficznych potrzeb. Istnieje zatem konieczność opracowywania strategii wsparcia dla wykładowców w zakresie zwiększenia kompetencji metodycznych. Szkoleń wymagają również pracownicy administracyjni - powinny one dotyczyć obsługi studentów z niepełnosprawnościami oraz alternatywnych i adaptacyjnych sposobów komunikacji werbalnej i pisemnej (czyli np. używania dobrze oświetlonych tablic ogłoszeniowych zawieszonych na wysokości oczu czy tekstu pisanego z wykorzystaniem dużej i kontrastowej czcionki).

W ramach projektów europejskich DARE Uniwersytet Jagielloński przy współpracy z trzema innymi europejskimi uczelniami opracował pakiet szkoleniowy na temat świadomości niepełnosprawności, rozszerzający kompetencje metodyczne wykładowców o umiejętność kształcenia osób niepełnosprawnych w trakcie zajęć uniwersyteckich. Podnoszenie poziomu kwalifikacji zawodowych nauczycieli akademickich w zakresie problematyki niepełnosprawności w środowisku uczelnianym miałoby odbywać się poprzez: „dostarczenie wiedzy na temat definicji niepełnosprawności, jej rodzajów, fizjologicznych oraz psychologicznych konsekwencji, barier w pełnym dostępie do kształcenia i życia społecznego; wyposażenie w umiejętność skutecznego komunikowania się z osobami niepełnosprawnymi; zwalczanie stereotypów i uprzedzeń na temat osób niepełnosprawnych; rozwijanie otwartej i aktywnej postawy w zakresie wspierania studentów niepełnosprawnych w procesie kształcenia; promowanie kultury różnorodności w środowisku edukacyjnym i życiu społecznym; doskonalenie umiejętności korzystania z technologii informacyjnych i komunikacyjnych w sektorze edukacji” (Nowak-Adamczyk 2014, s. 209). Szkolenia prowadzone są w trybie stacjonarnym w postaci treningu 
grupowego oraz zdalnego nauczania zintegrowanego z portalem edukacyjnym www.DareLearning.eu, poświęconym kształceniu osób niepełnosprawnych w głównym nurcie edukacji. Zajęcia stacjonarne dopełnia kurs e-learningowy, na którym w ramach indywidualnego szkolenia odbywa się podsumowanie kluczowych treści poruszanych podczas spotkań grupowych. Program szkolenia obejmuje następujące kwestie: kontekst prawny edukacji włączającej, modele niepełnosprawności (medyczny versus społeczny), mity i stereotypy na temat osób niepełnosprawnych, rola języka w konstruowaniu społecznego wizerunku osób niepełnosprawnych, charakterystyka wybranych niepełnosprawności, możliwe trudności w studiowaniu osoby $z$ daną niepełnosprawnością i sposoby adaptacji jej studiów. Każdy moduł szkolenia wieńczy interaktywny kwiz, dający szansę sprawdzenia wiedzy dotyczącej danej niepełnosprawności (Nowak-Adamczyk 2014).

Proponowane szkolenia pozwalają na uzyskanie kompetencji w zakresie: skutecznej komunikacji z osobą niesłyszącą, oceniania prac pisemnych studentów z dysleksją, przeprowadzania egzaminu dla osoby niewidomej, radzenia sobie podczas zajęć, w których bierze udział student doświadczający określonych trudności psychicznych, stosowania adaptacji studiów w celu wyrównywania szans edukacyjnych niepełnosprawnych przy jednoczesnym utrzymaniu kryteriów merytorycznych zajęć. Dostosowanie procesu dydaktycznego do specyficznych potrzeb osób niepełnosprawnych polega m.in. na: stosowaniu zapisu w brajlu lub w wersji elektronicznej (niepełnosprawność wzrokowa), przedłużaniu czasu trwania egzaminu, wykorzystywaniu wsparcia tłumacza języka migowego (niepełnosprawność słuchowa), organizacji egzaminów w osobnych pomieszczeniach, indywidualizacji terminów egzaminów (dla osób z chorobami psychicznymi) (Nowak-Adamczyk 2014).

Działania wobec wspólnoty studenckiej, mające na celu wyrównanie szans edukacyjnych jej niepełnosprawnych członków, polegają m.in. na kształtowaniu prawidłowych postaw wobec niepełnosprawności oraz budowaniu nieformalnego systemu wsparcia dla studentów z niepełnosprawnością. Podejmowane są konkretne kroki, np.: integracja i uświadamianie, angażowanie sprawnych studentów do roli asystentów osób niepełnosprawnych, przewodników osób niewidomych, rozwijanie wolontariatu studenckiego, szkolenia samorządów studenckich.

\section{Adaptacja otoczenia fizycznego}

Obiekty użyteczności publicznej oraz otoczenie zewnętrzne powinny być przystosowane do funkcjonalnych możliwości wszystkich osób, również z obniżoną sprawnością fizyczną, psychiczną, sensoryczną czy umysłową. W ocenie otoczenia fizycznego bierze się pod uwagę jego dostępność architektoniczną i wyposażeniową, zapewniającą orientację w przestrzeni, sprawność poruszania się i funkcjonowania w ramach czynności życia codziennego (ADL i IADL), dostępność informacji, bezpieczeństwo i transport. W przypadku uczelni najczęściej adaptowane są: 
budynki, zewnętrzne otoczenie i ciągi komunikacyjne, miejsca zakwaterowania studentów i transport. W modyfikacji środowiska fizycznego w kierunku zaspokojenia potrzeb osób z różnego rodzaju niepełnosprawnościami bierze się pod uwagę głównie: zewnętrzne i wewnętrzne ciągi komunikacyjne, wejścia do budynków, schody, pochylnie, podłogi, windy, oświetlenie, kolorystykę, kontrast, oznaczenia i druk. W ramach adaptacji wyposażenia wykorzystywane są najnowsze technologie (dostępne na uczelni lub wypożyczane), np. specjalne klawiatury dla osób z niesprawnością rąk czy komputery ze specjalistycznym oprogramowaniem.

Stwarzanie studentom warunków do pełnego udziału w procesie kształcenia i badaniach naukowych, o których mówi ustawa, to zapewnienie pełnej dostępności architektonicznej uczelnianych kampusów, nie tylko budynków dydaktycznych, ale również administracyjnych, sportowych, mieszkalnych oraz miejsc o przeznaczeniu kulturalnym, gastronomicznym lub handlowym. Stosowane są rozwiązania adaptacyjne dwojakiego rodzaju: uniwersalne i specyficzne dla osób niepełnosprawnych. Projektowanie uniwersalne z założenia służyć ma wszystkim użytkownikom, bez względu na wiek czy stopień sprawności, np. szerokie wejścia wyposażone w automatycznie otwierane drzwi ułatwiają funkcjonowanie nie tylko osobom na wózkach inwalidzkich, a antypoślizgowe podłoże nie jest jedynie dla tych, którzy mają trudności z poruszaniem się, podobnie komunikaty głosowe w metrze pomocne są nie tylko dla osób z uszkodzonym wzrokiem. Projektowanie pod kątem potrzeb osób niepełnosprawnych ukierunkowane jest na konkretny rodzaj niepełnosprawności, choć i tutaj respektowana jest zasada uniwersalizmu, np. wysokość krawężników nie powinna przekraczać $5 \mathrm{~cm}$ ze względu na użytkowników wózków, ale nie może być mniejsza niż $2 \mathrm{~cm} \mathrm{z}$ uwagi na potrzeby niewidomych poruszających się z białą laską, dla których wyczuwalna krawędź krawężnika stanowi ważny punkt orientacyjny. W ramach adaptacji wyposażenia dla osób poruszających się na wózkach stosuje się np.: lady (w stołówce, szatni) montowane na odpowiedniej wysokości czy tablice z możliwością regulacji wysokości w salach dydaktycznych, ze względu na studentów z dysfunkcją słuchu - tablice multimedialne czy system alarmowy wyposażony w sygnalizację świetlną, a z uwagi na osoby słabowidzące - kontrastowe oznaczenia ciągów pieszych ułatwiające poruszanie się.

\section{Zakończenie}

Studia dają możliwość nie tylko zdobycia zawodu, zwiększenia szans na rynku pracy i podwyższenia społeczno-ekonomicznego statusu, ale znacząco wpływają na życiową autonomię i rozwój osobisty, co dla osób doświadczających niepełnosprawności ma wyjątkowe znaczenie. Nim jednak dostaną się one na studia, a później z powodzeniem je ukończą, borykają się wielorakimi trudnościami wynikającymi z doświadczanej niepełnosprawności. Bariery w dostępie do szkolnictwa wyższego wymienione przez Ewelinę Krzymowską (Krzymowska 2014) można podzielić na: edukacyjne (niski poziom nauczania w szkołach specjalnych), 
finansowe (alokacja dotacji dla uczelni kształcących osoby z niepełnosprawnością, niski status materialny studentów z niepełnosprawnością), psychologiczne (brak wiary we własne możliwości osób z niepełnosprawnością), świadomościowe (niski poziom świadomości potencjału osób niepełnosprawnych wśród pracowników uczelni), adaptacyjne (brak organizacyjnego przygotowania uczelni do kształcenia osób z różnego typu dysfunkcjami), strukturalne (nierówny dostęp do uczelni w poszczególnych regionach kraju). Dokonana w niniejszym artykule analiza doświadczeń oraz potrzeb niepełnosprawnych studentów pozwoliła jednak wskazać na pozytywne zmiany, dokonujące się w zakresie podnoszenia stopnia dostępności uczelni wyższych dla osób z różnego typu niepełnosprawnościami. Doceniając poczynione w tym zakresie wysiłki, warto wymienić najważniejsze wyzwania w procesie adaptacji polskich uczelni, mającym za zadanie stworzyć niepełnosprawnym studentom warunki do pełnego udziału w kształceniu i badaniach naukowych.

W ramach wyrównywania szans edukacyjnych osób niepełnosprawnych celem kształcenia wyższego w Polsce powinno być osiągnięcie takiego ich udziału w społeczności akademickiej, aby odsetek niepełnosprawnych absolwentów szkół wyższych był porównywalny z odsetkiem osób pełnosprawnych wykształconych na tym poziomie. W tym kontekście znaczenia nabiera kwestia formalnego orzekania o stanie niepełnosprawności. Otóż według danych pochodzących ze spisu powszechnego (Główny Urząd Statystyczny 2013) w 2011 roku liczba osób niepełnosprawnych biologicznie (bez orzeczenia) zwiększyła się o ponad pół miliona (55,5\%) w stosunku do roku 2002 roku, kiedy też przeprowadzono takie badania (1 006600 versus 1565 60o), przy czym wyraźnie zmniejszyła się, o blisko półtora miliona, populacja osób niepełnosprawnych prawnie (z orzeczeniem) (4 450100 versus 3 131500). Osoby niepełnosprawne nie posiadają żadnego orzeczenia z powodu doświadczania przejściowej niepełnosprawności (wypadki, kontuzje) lub niezakończonej biurokratycznej procedury orzekania, albo też nie ujawniają go z obawy przed ostracyzmem społecznym (np. w przypadku choroby psychicznej, nowotworowej, padaczki, cukrzycy, stwardnienia rozsianego). Jednym z najważniejszych wyzwań przyszłości jest zatem objęcie wsparciem każdego, kto jest w stanie wykazać negatywne dla procesu kształcenia następstwa doświadczanej niesprawności czy choroby, na takich samych prawach, jakie przysługują studentom dysponującym orzeczeniami. W każdej sytuacji ograniczenia sprawności utrudniającego pełne uczestnictwo w procesie kształcenia i generującego sytuację edukacyjnego wykluczenia powinny znajdować zastosowanie uczelniane procedury adaptacyjne, mające na celu zapewnienie jak najszerszej dostępności procesu naukowo-dydaktycznego. W kwestii tej potrzebne jest podejście elastyczne, pozbawione nadmiernej biurokracji.

Zdaniem Aleksandra Waszkielewicza (Waszkielewicz 2011), prezesa zarządu Fundacji Instytut Rozwoju Regionalnego, warunkiem wydatkowania ministerialnej dotacji na dostosowywanie procesu kształcenia do potrzeb studentów z niepełnosprawnością nie jest orzeczenie jako takie, właściwie potrzebne tylko do ubiegania 
się o stypendium specjalne. Z sygnowanych przez Polskę umów międzynarodowych (np. Powszechnej deklaracji praw człowieka, Konwencji w sprawie zwalczania dyskryminacji w dziedzinie oświaty, Międzynarodowego paktu praw gospodarczych, społecznych i kulturalnych) wynika, że brak orzeczenia nie może ograniczać prawa do równych szans edukacyjnych. Punktem wyjścia działań adaptacyjnych powinny być ograniczenia funkcjonalne, wnikające z obniżonej sprawności fizycznej, psychicznej czy umysłowej danej osoby.

Kolejnym wyzwaniem w procesie dostosowywania systemu kształcenia akademickiego do potrzeb studentów z niepełnosprawnościami jest tworzenie zbiorów czytelniczych $w$ formach alternatywnych. Wiąże się to $\mathrm{z}$ digitalizacją zbiorów bibliotecznych i udostępnieniem ich studentom z trudnościami w odczytywaniu druku, np. z dysfunkcją wzroku, dysleksją. Niektóre ośrodki akademickie (np. Uniwersytet Warszawski, Politechnika Wrocławska, Akademia Górniczo-Hutnicza w Krakowie) wdrażają system adaptacji materiałów dydaktycznych dla niewidomych i słabowidzących studentów, dając w ten sposób przykład innym uczelniom.

Za ważne, jeśli nie kluczowe, zadanie w kształceniu studentów niepełnosprawnych na poziomie akademickim należy uznać rozwijanie doradztwa zawodowego skierowanego do niepełnosprawnych uczniów i studentów oraz wspieranie ich w wejściu na rynek pracy. W wyniku zaniedbań na tym polu ukończenie z sukcesem studiów nie przekłada się na znalezienie pracy. Inwestycje poczynione w rehabilitację i edukację niepełnosprawnych osób nie zwracają się w postaci osiągnięcia przez nie samodzielności życiowej i integracji społecznej, jakie daje podjęcie pracy zawodowej. Praktyka pokazuje, że wykształcone niepełnosprawne osoby są bardzo podatne na marginalizację społeczną, wymagają wspierania w ramach kolejnych programów realizowanych na poziomie lokalnym i ogólnokrajowym (Giermanowska, Racław 2014). Badania dowodzą, że niepełnosprawni absolwenci szkół wyższych to grupa niezwykle silnie zmotywowana do pracy, mobilna i zahartowana w pokonywaniu przeciwności losu, jednak pozbawiona profesjonalnych instytucji wspierających w staraniach o pracę oraz promujących zatrudnienie niepełnosprawnych wśród pracodawców, co budzi frustrację z powodu niemożności zaspokojenia rozbudzonych aspiracji zawodowych (Giermanowska, Racław 2014).

Wśród wyzwań związanych z dostosowywaniem polskich uczelni do potrzeb niepełnosprawnych studentów należy również wymienić podnoszenie wśród pracowników naukowych, dydaktycznych, administracyjnych oraz technicznych świadomości i poziomu wiedzy na temat specyfiki funkcjonowania osób z różnego rodzaju niepełnosprawnościami oraz włączania tych zagadnień do akademickiego systemu szkoleń i działań promocyjnych oraz programów kształcenia nauczycieli. Warto także zawczasu podjąć temat tzw. niepełnosprawności kulturowej, związanej z kwestiami adaptacyjnymi zagranicznych studentów i mieszkańców na tle kulturowym, rodzącymi trudności, z którymi w wymiarze ogólnospołecznym Europa mierzy się już dziś. Istotne jest, aby działania wspierające niepełnosprawnych 
studentów na polskich uczelniach miały charakter systemowy i były skierowane do całej społeczności akademickiej.

\section{Bibliografia}

BAEL (2010). Badanie aktywności ekonomicznej BAEL, dane za I kwartał 2011 roku, dostępny na: www.stat.gov.pl (otwarty 7.12.2012).

Fornalik I. (2006). Osoba niepełnosprawna w szkole wyższej - o postawach i problemach pracowników naukowo-dydaktycznych. W: Kosakowski C., Krause A., Przybyliński S. (red). Pomiędzy teoriq a praktyką. Olsztyn: Uniwersytet Warmińsko-Mazurski.

Giermanowska E., Racław M. (2014). Niepełnosprawni absolwenci szkół wyższychnowy potencjat zawodowy czy narastajacy problem społeczny. „Acta Universitatis Lodziensis. Folia Sociologica", nr 50, s. 7-26.

Główny Urząd Statystyczny (2013). Ludność i gospodarstwa domowe. Stan i struktura społeczno-ekonomiczna. Czesść I. Ludność. Narodowy Spis Powszechny Ludności i Mieszkań 2011. Warszawa: GUS.

Główny Urząd Statystyczny (2014). Dostępny na www.stat.gov.pl (otwarty 11.01.2016). Krzymowska E. (2014). Student z niepełnosprawnością w Polsce. „Niepełnosprawność. Dyskursy Pedagogiki Specjalnej”, nr 15, s. 100-110.

Kwaśniewska G. (2006). Student z niepełnosprawnościa - zadania i wyzwania. W: Palak Z., Lewicka A., Bujnowska A. (red). Jakość życia a niepełnosprawnośćkonteksty psychopedagogiczne. Lublin: UMCS.

Nowak-Adamczyk D. (2014). Świadomośćniepetnosprawności warunkiem kształcenia inkluzywnego. „Przegląd Naukowo-Metodyczny. Edukacja dla Bezpieczeństwa”, nr 3, s. 201-215.

Paszkowicz A., Garbat M. (2005). Wykształcenie szansą awansu społecznego osób niepełnosprawnych. W: Woźniak M.G. (red.). Nierówności społeczne a wzrost gospodarczy. Kapitał ludzki i intelektualny, cz. 2. Rzeszów: Uniwersytet Rzeszowski.

Perdeus-Białek M., Nowak-Adamczyk D. (2013). Równe traktowanie na Uniwersytecie Jagiellońskim. Przewodnik po zasadach wsparcia edukacyjnego dla studentów i doktorantów. Kraków: Uniwersytet Jagielloński.

Rozporzadzenie Ministra Nauki i Szkolnictwa Wyższego z dnia 25 września 2014 r. w sprawie warunków, jakim muszą odpowiadać postanowienia regulaminu studiów w uczelniach (Dz.U. 2014, poz. 1302).

Szpunar M. (2010). Życie z piętnem. Studia jako próba zdeprecjonowania stygmatu osoby niepelnosprawnej. „E-mentor”, nr 2, s. 62-69.

Ustawa z dnia 27 lipca 2005 r. Prawo o szkolnictwie wyższym (Dz.U. nr 164, poz. 1365).

Waszkielewicz A. (red.). (2007). Dostępność polskich wyższych uczelni dla osób niepełnosprawnych. Kraków: Fundacja Instytut Rozwoju Regionalnego, Instytut Badań Marketingowych i Społecznych VRG Strategia. 
Waszkielewicz A. (2011). Prośba do MNiSW o wyjaśnienie statusu osób niepełnosprawnych, nr pisma: FIRR/2011-09-19/AW/PIS/1. Kraków: Fundacja Instytut Rozwoju Regionalnego.

\title{
STUDENTS WITH DISABILLITIES - EXPIERIENCES, NEEDS, CHALLENGES
}

\begin{abstract}
The article analyzes the activities of Polish institutions of higher education to create conditions of full participation in the educational process for students with disabilities and also describes the tasks undertaken in this regard in relation to: the students with disabilities, academic staff, student community and the physical environment. It outlines previous experiences and current challenges in the field of adaptation of the academic education to the needs of people with different types of disabilities.
\end{abstract}

Key words: disability, education, studies, adaptation, inclusion

Marlena Kilian - doktor, absolwentka Akademii Pedagogiki Specjalnej w Warszawie ze specjalnością tyflopedagogika. Aktualnie pracuje na Wydziale Nauk Pedagogicznych Uniwersytetu Kardynała Stefana Wyszyńskiego w Warszawie, na etacie adiunkta, gdzie w zakresie naukowo-dydaktycznym zajmuje się zagadnieniami pedagogiki specjalnej, zwłaszcza w kontekście niepełnosprawności i rehabilitacji osób w starszym wieku, a także rehabilitacji osób niewidomych i słabowidzących. Pełni funkcję pełnomocnika rektora UKSW ds. osób niepełnosprawnych. Adres do korespondencji: Wydział Nauk Pedagogicznych UKSW, ul. Wóycickiego 1/3, budynek 11, 01-938 Warszawa. Adres e-mail: m.kilian@uksw.edu.pl. 